\title{
Ideology isn't in the Answer, it's in the Question: An Interview with Slavoj Žižek
}

\author{
Ben Gook* and Slavoj Žižek** \\ *University of Melbourne, Australia, bgook@unimelb.edu.au, \\ https://unimelb.academia.edu/BenGook \\ **http://zizek.uk/
}

Abstract: An interview with Slavoj Žižek, in which he discusses crucial topics central to both his thought (psychoanalysis, philosophy, Hegel, film) as well as broader conversations over the past decade (capitalism, China, universal basic income, ecology, authoritarianism, protest movements).

Keywords: ideology, psychoanalysis, capitalism, universal basic income, ecology, China, authoritarianism, Occupy

In September 2011, Slavoj Žižek visited Australia to give a lecture at the Sydney Opera House as part of the Festival of Dangerous Ideas. I interviewed Žižek the following morning in the lobby of his hotel on Sydney Harbour. We had scheduled the interview for an hour but spoke for nearly an hour and a half. The conversation covered some topics he had talked about in his lecture, and his other preoccupations at that stage he was completing what would become Less than Nothing, the long book on Hegel. ${ }^{1}$

What's remarkable in revisiting the transcript, almost a decade later, is the number of topics that remain significant - or that have, in fact, become even more central. These include ecology, China, universal basic income, crisis, forms of knowledge and communication, authoritarianism and modes of authority, as well as the question of horizontal versus vertical organization (e.g. the Occupy moment and its repercussions in politics, both parliamentary and extra-parliamentary). Among other things, Žižek discusses Berlusconi as the future of popular political authority - a comparison many have since come to make in the years since Trump's ascension:

Again, it's clear what is slowly emerging, the contours of this new authoritarian system. It's crucial not to fall into this trap, as many leftists do, of shouting "fascism!" It's absolutely not the same as the old-time fascism. It can even tolerate - this is why I like very much to think about - although I'm terrified by him - figures like Berlusconi in Italy. When you have power getting stronger and stronger, but at the same time totally non-dignified power, making fun of itself and so on, not taking itself seriously. This is something very interesting. I really think that Berlusconi is one of the waves of the future. A power which systematically undermines its own dignity. It's no longer, as in Stalinism or fascism, a big dignified leader, if you make fun of him you immediately disappear

\footnotetext{
1 Slavoj Žižek, Less Than Nothing: Hegel and the Shadow of Dialectical Materialism (London: Verso, 2012).
} 
or whatever. No! Something is deeply changing in the very mode authority functions today.

For all its apparent topicality and prescience - discussing such shifts a good half a decade before Trump arrived - the interview was never published. The Australian magazine that had commissioned it deemed it "too depressing." They had also sent an expensive photographer to New York to get original images of Žižek - but these were judged too "sad" for a magazine otherwise full of extended interviews with "social entrepreneurs" and artists boasting of how positive psychology and just the right amount of trauma made them successful.

Sad Slavoj got spiked by the magazine. Nevertheless, it was possible, thanks to triple $C$, to take it out of the desk drawer and put it into circulation. I have lightly edited the transcript that follows for length.

\section{Žižek: The Negative Enthusiast}

Ben: I'll start with two basic questions. Why philosophy today and why psychoanalysis?

Slavoj: It's a good question, because the usual doxa is that both are out of date. The thinking today about psychoanalysis is that maybe, if anything at all, it had some value in the Victorian times of sexual oppression but a) today we no longer have to repress sexual desires and b) in any case we have now the cognitivist or behavioral approach to psychology, which works much better. With philosophy it's the same. Look at the last book - which is very bad, incidentally - by Steven Hawking, where he begins with "philosophy is dead." The questions, which were once philosophical questions - "does the world have an origin," "is there free will" - he says, can be answered by modern sciences of philosophy: it's over. Well, to be very simple, I disagree on both counts.

First, psychoanalysis. No, I think that Freud was bothered by a certain paradox which was not the obvious fact of oppression - like if you feel moral oppression - but how permissivity, if you are ordained to do something it sabotages your desires even more effectively. The problem is, as every intelligent adolescent knows the problem, not a father who tends to say, "you shouldn't mess with sex." This is wonderful. You will want to transgress it and so on. The problem is the obscene father who says, "have you already screwed a girl, eh, how about that?" That makes you impotent. Why that response? Why today, when we live in permissive societies - when we are bombarded by ideas of what the goal of your life should be, a kind of enlightened hedonism, to have a lot of fun - why is there so much impotence, frigidity and so on?

This paradox was encapsulated in the Freudian notion of superego. Superego is the agency soliciting you to enjoy, but at the same time sabotaging you. So I claim all the paradoxes we encounter today of this permissivity which sabotages pleasures much more effectively than old prohibitions, this is a sign, I think, that it's only now after the disintegration of so-called "traditional patriarchal authority" that the time of psychoanalysis is coming.

As for philosophy, I claim it's similar. With all sciences and their impact on our daily lives - isn't it that we cannot any longer rely on old moral standards? We see with problems like biogenetics, changing of personality or all that, it's something totally new. You need to think as a philosopher. In the old times the idea was philosophers are just eccentric people who dig too deep, but in everyday life you're just using moral instinct or relying on what tradition tells you to do. No, today this is no longer the case. Again, with all these new problems - What does all this biogenetics, DNA, blah blah blah, what does all this mean for our freedom? 
The traditional solution is the [Jürgen] Habermas solution, which is to keep the distinction. To claim, positive science may teach us etc., but in ethics we must act as if we are free. No, that's not good enough because today you could do things, like what if with drugs or even worse with some genetic manipulations, I can change your very psychic dispositions - precisely the ones which affect your moral activity? What does this mean for our sense of freedom and so on?

So, I think it's the same with psychoanalysis. Maybe the time for philosophy is only coming, in the sense that philosophy means for me freedom to reflect upon new situations where obviously we are in an ethical or political deadlock but the reference to traditional wisdom, morality - doesn't help, doesn't provide orientation.

Ben: You've said, too, the philosopher today has to repose the questions rather than answer them.

Slavoj: That's elementary for me. We cannot provide answers, but again this is my old mantra: that maybe even more important than providing answers is to change the questions, to show how the way we formulate a problem can be part of the problem. For example, the obvious political example. Media outlets are telling us the great struggle today is between enlightened liberal permissivity and fundamentalism.

I ask myself, is this the true dilemma? Is it not that it is something in today's global capitalism that generates new forms of fundamentalism from Afghanistan to United States themselves. Did you read that wonderful book, it's not big theory but an interesting description: Thomas Frank, Whatever Happened to Kansas? It's a simple proof how Kansas, historically the most progressive state of the United States, the most violently, in the good sense violently, anti-racist state - John Brown is from Kansas and so on - how it, in the last 30 years, turned into the most fundamentalist state.

That's what we should ask, what is it in modern global capitalism that pushes some people towards certain kind of fundamentalism. Fundamentalism is for me a modern global phenomenon. It's something totally inherent to capitalist dynamics.

The question should not be how to fight fundamentalism but what is it in modern capitalism which although it's zero-level ideology is liberal permissivity, it nonetheless, at the same time pushes people towards fundamentalism. And again, what I developed yesterday [at the event], for example there is racism and sexism - but why do we automatically translate this into problems of "tolerance"? You know these are ideological notions. Ideology is not simply an illusion. Ideology names real problems but it names real problems in a mystifying way.

For example, of course ecology is a mega problem. Fuck it, maybe we will all die because of it. You notice how a tremendous amount of ideology invested there. First, all this bullshit about reading meaning into it, like ecological catastrophes - you don't even have to be directly theological, claiming divine punishment, but you know you can do it more like "this is the punishment for our modern way of life," "too much exploiting nature" and so on.

All this secularized religious logic of, "with capitalism we broke with Mother Nature, with our human hubris we thought we could be masters of nature, but we should modestly find out place within nature." Even somebody as progressive as Eva Morales goes into "capitalism killed Mother Nature," to which maybe you know my answer this is at least one good thing capitalism did.

You know what I mean by this? I'm not saying ecology is not serious. I just think that precisely to seriously confront ecology, one has to drop totally this myth of some 
Mother Nature primordial balance from which we fell. No, as good Darwinists, like Stephen Jay Gould, teach us: nature is in itself crazy, full of imbalances, full of catastrophes. This is really bad news. It means we cannot, by culpabilising ourselves, rely on some primordial natural balance, like we think that we went too far, so let's return to some natural - there is no natural balance. Nature is full of catastrophes and so on.

So again, this is the main task of us philosophers today. We cannot provide answers. But we can correct the questions, because ideology is not in the answer, it's in the question.

Ben: One of the themes in the background of your talk here in Sydney is that grand political ideas have been off the table for a while now, and instead there has been pleasant but fairly conservative focus on minoritarian, local, small initiatives, like farmers' markets and organic food.

Slavoj: All this is sympathetic. Maybe I was too brutal. I'm just saying it's too much of a feel good, small-level politics.

Again, where is the true alternative, what to do? There still is this big problem: is there truly an alternative to capitalism? The welfare state doesn't work. All this Porto Alegre World Social Forum bullshit doesn't work. I'm getting tired of it, like "local communities organizing themselves," blah, blah. Many leftists accuse me of being just too pessimistic. No! I'm just trying to be a realist. I'm tired of these illusions, of this idea, "once people are allowed to organize themselves, we will have these 'small is beautiful' self-relying economies." No! We live in a complex world, where more and more the problem will be that of large-scale organization and reorganization.

My favourite example is Fukoshima in Japan. Imagine, why not, a stronger catastrophe and the northern half of Japan becomes non-inhabitable. Obviously, there would have been a need for a large transfer of populations. Obviously, this will be our future. This desertification of Africa will continue, now in Somalia there are new deserts. On the other hand, because of global warming parts of Russia, for example Siberia, will become more inhabitable. How will these large shifts of population happen? Who will do it? It cannot be done in the old, pre-modern way of non-organized movements of population - this means war today, this is a catastrophe today. I think there still is this problem of large-scale organization to organize large-scale changes. We don't have the formula how to do it, but we will have to do it.

Ben: But is that why communism is a dangerous idea now, because it's a grand

Slavoj: I would say - I didn't want to go into this yesterday - but I will even be tempted to say that: no, the dangerous ideas are capitalism and standard ecology. Communism is not a dangerous idea. It's just an approach where you focus on commons, which allows you to detect where the dangers are today. It's not a dangerous idea, it's an idea which allows you to see the dangers in the way things are now. This is important today.

Again, as I emphasize, I hope enough because I repeated this three or four times: no nostalgia for 20th century or whatever. What I mean by communism is a problem not an answer. I don't have any clear idea what to do. All I know is our problems are the problems of commons.

Ecology - if you don't approach it, then we may be living in new globally catastrophic times where maybe only an isolated minority in secluded areas will 
survive. The same with, again, the fundamental fact of today's capitalism, the Berlin Wall fell, yet there are new walls all around. We are clearly approaching a new apartheid society, the same with biogenetics.

My God, I have nothing against the Chinese but when I visited China, I don't know how, but I met some guys there from their Academy of Sciences, biogenetics section or whatever. They showed me a wonderful document where they say in the official program, that the goal of biogenetic research in China is to take care of or direct or they use some Confucian term, I don't know what - of the physical and psychological wellbeing of the Chinese people. They really want to regulate it.

I'm saying what should be our answer to this? How to prevent not only a private company but a state, some agency not democratically controlled to direct this, and so on. Again, this is a problem of our commons. Biogenetics is our common shared inheritance, the same as I repeat all the time, apropos intellectual property. I claim this really is a problem with capitalism because more and more knowledge or information is becoming the ultra commodity.

But the problem with knowledge is that there is something inherently communist in knowledge. In what sense? This is my old stupid example. If I have a material object like a bottle of water or beer, there private property works because if I drink it you cannot drink it. If I use it, it is less useful for you. But knowledge has a paradoxical property that the more it circulates the more it enriches itself. If you allow knowledge to freely circulate it not only doesn't get used, it's a totally different logic. Which is why we have this more and more of a crisis today.

The problem is: forms of collective knowledge, that very frame is getting privatized. Which is why, for example, developments like computer clouds are I think crucial. You know, there is a cloud out there. The problem is who controls the cloud. These are big problems. I don't even have clear solutions. I know - I think that capitalism doesn't work here - the greatest proof is what? Microsoft itself. That the state had to intervene to save free markets there. You have this paradox that - this is for me the clearest argument against free market, how with Bill Gates and so on the state had to intervene very strongly to maintain a minimum of free market to prevent monopoly and so on.

Again, I know that simple state control doesn't work here. l'm just saying these are all communist problems, problems of commons. And all l'm saying is - l'm a moderate pessimist - if we do not gradually or in whatever way change our lives, one can already discern the figure of a negative society to come. A kind of a new authoritarian society which will no longer be the old fascism and so on, which is why when people ask me "What is your negative dystopian vision?" I tell them - this is my favourite case - did you see the move? I love it, Terry Gilliam's Brazil. You should [see it]. It's kind of a comical vision of Orwellian society, where you know it's a crazy society where at the level of private lives, we are totally free, with all our pleasures, but at the same time it's a kind of - everything is controlled. It's a kind of society which is, at the same time, controlled and authoritarian, but again at the same time, at the level of private lives totally permissive. You can have all your sexual pleasures, all your idiosyncrasies and so on. It will no longer be the old type of totalitarianism which wants to control your private lives and so on. Even China is more and more moving in this direction.

This is, I think, a very - as I hinted yesterday - a very interesting phenomenon. How come today communists in power seem to appear more and more the most efficient form for successful capitalism? If I were an honest liberal, I would really worry about it. This tendency in capitalism itself which seems to demand more and more authoritarian rule, or at least a depoliticized rule, it's very interesting to see how the Chinese regime legitimises itself: in purely post-political terms. They say we are just 
trying to maintain stability, dignity, or whatever. It's pure ethico-pedagogical legitimization. This is what works.

Again, it's clear what is slowly emerging, the contours of this new authoritarian system. It's crucial not to fall into this trap, as many leftists do, of shouting "fascism!" It's absolutely not the same as the old-time fascism. It can even tolerate - this is why I like very much to think about - although I'm terrified by him - figures like Berlusconi in Italy. When you have power getting stronger and stronger, but at the same time totally non-dignified power, making fun of itself and so on, not taking itself seriously. This is something very interesting. I really think that Berlusconi is one of the waves of the future. A power which systematically undermines its own dignity. It's no longer, as in Stalinism or fascism, a big dignified leader, if you make fun of him you immediately disappear or whatever. No, something is deeply changing in the very mode authority functions today. Here again I claim we need psychoanalysis but sorry, I got lost...

Ben: Well, there are two directions we can take from that, one about politics but the other is about the effects of all this on our psychology and everyday life. In all your work, you've been interested in the effects on the modern subject of these big changes, in culture, politics, and the economy.

Slavoj: A new subject is emerging which undermines the old duality of either personal freedom, hedonism, or state authority and so on. It's a new hedonist subject. Basically, what is society today demanding of us? It's no longer, "sacrifice yourself for some big cause." No. It's basically a hedonist demand. It's a quite unique moment in the history of ideology. For the first time, maybe in the history of humanity, the state is telling you, basically, "be true to yourself, have a good time, realize your true potentials."

With all this freedom and so on, and even just so that this freedom is guaranteed, we are more and more, in a way, controlled, manipulated, and so on. Again, it's - we cannot simply play this duality of freedom versus control. What if we have control, which justifies itself as control on our behalf to guarantee the conditions for our freedom and so on? Something really new is emerging here, I claim, kind of a post-political era. It worries me. That's all.

Ben: Well, to change tack a bit, cinema is something else that's been a strong presence in your work as a theorist. But it's also something you've been involved in yourself: namely, the documentary Žižek! and the three-part Pervert's Guide to Cinema series with Sophie Fiennes.

Slavoj: I'm not kidding with what I will tell you now. I haven't seen one of them. No, no, no. Not that I am against them. Obviously I'm not, otherwise I wouldn't have participated in them, but I have problem with myself. When I see myself on screen with all my nervous tics and so on, I cannot stand myself. I like a little bit more the last one, Pervert's Guide to Cinema, because it's at least not about me.

Now, with pleasure, I did with [Sophie Fiennes] a new one - I just finished now, before coming on this trip to Australia. Three weeks ago, we finished shooting a Perverts sequel in Dublin: Pervert's Guide to Ideology. I did that one with pleasure. But it was very traumatic for me to shoot these movies. I am nonetheless a theorist. What matters for me is a line of thought. It's so terrifying for me when you are treated not as a theorist but as an actor-presenter: like I improvised some good ideas, for about a quarter of an hour, then Sophie Fiennes tells me "Slajov, it was brilliant - but the light 
was wrong in the back. Can you repeat it?" No! Fuck you, I cannot! It was so traumatic for me to do this. I hate it.

At the same time, I think it's good to - like, this one will be much more political, Pervert's Guide to Ideology, obviously, no? We tried to make it funny, but we politicized it much more than the last one. The formula will be the same as Pervert's Guide to Cinema: using clips from cinema, but it will all be focused on how ideology functions today and so I hope it will work.

Ben: The extension of that is you use a lot of cinema in your work.

Slavoj: But I must be very honest here. Only a minor part of it is real immanent cinematic analysis. Some of the things I wrote about Kieslowski, Tarkovsky, Hitchcock - this is real analysis, immanent analysis of the film form; where, if there is ideology or even theology, you find it immanent in the form itself. But let's be frank: a good part of my work is reference to cinema as simple exploitation. In the majority of my references to cinema I simply use it as an indication of how ideology works today. My thesis is very simple one: if you want see in a clear, distilled way today's ideology, look at Hollywood. It's a clearer image than in our much more confused real lives. It's simply, Hollywood as an indication of where we stand in ideology. Only rarely do I go into an immanent analysis. I would like to have more time to do that, but, basically, it's ideology, though again the bad news is that even with ideology l'm getting tired.

This is just selling old stuff, what I was doing here in Sydney, all this political analysis. Basically my real work for the last years was, silently, I was returning to philosophy. And I just did it. Some people thought it will never come to be, the big book on Hegel. No, it's being copy-edited now, over 1,000 printed pages. Here was my real work in the last years.

Ben: So you've sidelined cinema in that?

Slavoj: You know, I was always kidding a little bit. I'm honest to admit it. Quite a few of the films l've written about, I haven't seen them. For example, let me be embarrassingly open. Kieslowski, pretentious. I haven't seen even all of his Dekalogue frankly, or the trilogy - I think I overestimated the Colours trilogy, it's too pretentious, pseudo-deep and so on. Tarkovsky, I've seen Stalker and The Mirror and that's all l've seen. Otherwise, others l've only seen quickly with fast-forward on DVD. It's too boring. Rossellini, there's a long chapter in my Enjoy Your Symptom, I haven't seen any of his. ${ }^{2}$ I find him so pretentiously boring and so on.

Let's be clear here. I hate bluffing. It's not that I just can enjoy cheap commercial Hollywood, even that is getting more and more boring. I can quite enjoy some serious films but they are rare. If you ask me where is my heart today, it's some new independent Chinese cinema. Did you see - Jia Zhangke's Still Life? This is a true it's like the best of Antonioni reinvented in China. It's wonderful, just breathtaking.

In Hollywood I like certain marginal Hollywood, like which are the true masterpieces of Hollywood for me? Like did you see Robert Altman's Shortcuts, that movie I really like. Did you see Atom Egoyan's Sweet Hereafter? That movie - when the crippled girl at the end, they brought her to the court and she tells a lie. A lie which acts as a moment of truth. This is for me the best example of a Lacanian act, a lie but a lie producing a

2 Slavoj Žižek, Enjoy Your Symptom! Jacques Lacan in Hollywood and Out (New York: Routledge, 1992). 
truth effect. Then did you see Ang Lee's Ice Storm? There are masterpieces. My tastes are very serious here, like in literature. My true choices of the 20th Century are Kafka, the obvious one, and Beckett - not Joyce, Joyce is too pretentious, bluffing. Beckett is the true genius, I think.

I did a text on Beckett, to approach my true desire. Even I was ashamed to talk too much about it. It took me a long time to write. I'm in a way very conservative, like in pop culture. Maybe this shows in my age, but I think everything great happened between '65 and '75. It's the same with pop literature, like maybe there is something conservative but I - for example sincerely, because my son likes the movies - I tried to read Harry Potter stuff. I don't get it. I find the novels extremely boring and nonimaginative. I don't get it. With Lord of the Rings it's a bit better. I always liked this gothic totalitarian universe. That's a little bit better, but still who has time to read all that? My God, it's simply too much.

Ben: So, I guess cinema has the benefit of being a common language today, a short cut - and much shorter.

Slavoj: I don't have time to see them but to put it in this Hegelian idealist terms: it's as if now the spirit is shifting maybe from cinema to TV series. I think really great things are happening there, not only these high-quality series, like The Wire or what, all that stuff. But even the big - I'm not such a fan of Sopranos, it's a little bit too pretentious. But there are so many good series, I really think that maybe again, if you want to catch the spirit of the age it's more and more TV series, not cinema.

I just, for obvious reasons, have time to watch them. What I do is often, I'm either invited or just pass through China. My great spiritual experience there is to find a good pirate DVD store. There you know prices are incredible. The last time, this summer in August I was with my sons, one week Beijing, one week Shanghai, one week Hong Kong. In Shanghai we found the best DVD store. It was ridiculous. I bought all these rarely seen TV series, they were not such a success but I like them, like the new Sherlock Holmes, there is now the new Sherlock Holmes BBC series set up in today's London. It's interesting experiment. I bought the whole first season for a ridiculous three dollars. Price is not a question. The question is how much you can buy so that you will not have too much. Every time I go there I buy some 300-400 of them, which costs you less than one night of hotel.

This new Camelot, with Eva Green and so on, unfortunately they stopped it. It will not go on. But I did that one. Then Neil Jordan The Borgas, I did that one. So I try to watch it, but again I'm not strong enough to do a proper theory. Maybe I should read a little bit more to go into series theory. It's also an interesting phenomenon in the sense of how it's not limited to Hollywood. Not only in Latin America - I don't know how it is here but, in my country, and in other European countries, Latin American telenovelas are incredibly popular. They're a bit too much for me. I cannot watch them but it's an interesting phenomenon. I don't yet have a theory. It's frustrating. I'm really a freak of theory, like things for me have the right to exist only if they enable you to develop a theory based on them.

Ben: There was an interesting article recently in Radical Philosophy talking about both 'The Wire' and Gomorrah, that book about the Italian mafia. ${ }^{3}$

${ }^{3}$ David Cunningham, "Capitalist Epics: Abstraction, Totality and the Theory of the Novel," Radical Philosophy 163 (2010). 
Slavoj: That I find quite interesting - how, against this Godfather idea that nonetheless celebrates mafia, in Gomorrah you see the misery. I saw in a newspaper here an ad for The Whistleblower, a very interesting movie with Rachel Weisz. It's so dramatic, it's excellent not as art cinema but as a very naïve insight. It's based on a real story of an American policewoman, relatively young, who volunteered to work with the United Nations forces in Bosnia, Sarajevo, and then it was a nightmare. She worked in the special division focussed on abuses of women and so on. She discovered what you may well imagine, that not only were the United Nations officers themselves the main customers of illegal prostitution rings, but they co-organized them. The very forces organized sent there to protect abuse of women were deeply involved in white slave traffic and smuggling women.

It's a totally depressing story with no happy ending. She tried to render everything published. She was fired. The same guys involved in this traffic with women are now doing the same job in Afghanistan and Iraq. It's one of the darkest movies. There is nothing so smugly satisfying as - I hate them - those pseudo-Hollywood left movies like Pelican Brief and All the President's Men. Apparently, they're "very critical," oh my God, the President of the United States himself is corrupted and so on. But they're feelgood movies. The ultimate message is look in what a great country we live; two ordinary guys can bring down the mightiest men in the world. No - The Whistleblower such a dark movie. No bright hope. I like it but again I'm not saying it's a great movie.

Ben: You've said in the past that many leftists and artists are looking for a theory "master" to tell them what to do - but you don't want to be that person.

Slavoj: What's so interesting is that artists play a double game here. At the same time they claim "you theorists only want to exploit us and no we won't [let that happen]" but at the same time, they solicit us: "okay, I did the job, where is your theory?" As if we theorists, it's our duty to justify it, no?

No, I'm here very critical of art. I think that a lot of disgusting, snobbish things are going on today. I think there is something depressingly well organized in this big machinery of especially Biennales - the way even the most daring avant-garde artist is marketised, while the result is I'm basically totally not interested. From time to time they try to bribe me, like my God, a big name Indian artist's secretary approached me like "Mr. X would like very much for you to write a text apropos his new exhibition." Fuck off, I mean why? My idea is if they are interested in our work let them read our work. I don't want to become part of that machinery. Which is why I try to keep distance. I resist it. Even if they try literally to bribe me, because usually they have much more money. It's so funny how they treat you as if they can buy you for a couple of thousand dollars.

Once another big artist wanted to - telling me "what an honour, I allow you to write for my" - I told him "why don't you do a free drawing for my book cover?" They're not crazy. Their price is hundreds of thousands of dollars, so fuck off. I mean, no I think that today's artists are doing too well usually, the big names.

I'm afraid of creative people, especially poets. I'm for Plato here; I think Plato had a good idea: throw poets out of the city. If you look at the 20th Century, maybe you know my formula: behind every ethnic cleansing there is a poet. It's true for Yugoslavia, it's true for fascism, it's true for Rwanda even. 
This is what I wanted to say yesterday but there was not the chance. What do they mean by this festival's "dangerous ideas"? There is a way to claim you are dangerous which is just another case of this cheap commodifying provocation, "dangerous idea," this that. It's easy to be, in this cheap way, provocative.

The moment, even you get seriously provocative, you can be provocative in this sense but let's be seriously provocative. Let somebody say - I don't agree with it, but just the idea - "the Aborigines were stupid people here who deserved to disappear." What would have happened if somebody were to say this? This would have been a really dangerous idea. I don't agree with it, but my point is very simply - don't fuck with it. I mean there are dangerous ideas that are really dangerous, they should be prohibited - fuck it.

I'm bored by this pseudo-transgressive idea: "dangerous," "creative." No. Here I agree, even as a total atheist, with that guy with whom I began yesterday, [prolific orthodox Christian writer] G.K. Chesteron. You know that the most interesting thing in the world is orthodoxy. It's not boring. The cheapest, easiest way is to be subversive in this sense. You know what is happening in modern art? Anything goes. You can put there anything, go to some fucking thing like Saatchi gallery in London. Your intestines, a video of your colonoscopy, whatever, it's getting so boring, my God. I think we need new orthodoxy.

It's like architecture. I wrote a text, and I'm ashamed of it. I don't really know a lot of architects, but what exploded there, in that text, is my - how I despise these big names, Frank Gehry-style architecture, where you do buildings not for real people but you do buildings so that there will be books published about it. Like there is a bit of it even in the Sydney Opera House. It's not only the Frank Gehry and Bilbao stuff; I hate this new concept of cultural centres or art centres, which are supposed to be open to public but, I claim, are a new form of elitism and so on.

Here I'm very traditional leftist. What would have really interested me and I spoke with some architects who told me there is some stuff being done on that, namely on what? On - like what is happening in slums or Favelas in Latin America, it's not true that the architecture is simply just pragmatic. No, there are certain tendencies; even fashions and so on. It's incredible how much of what we would probably take or perceive as kitsch is practiced there.

No, again here I'm an old-fashioned leftist. I hate cities which try to revitalize themselves by paying tens of millions of dollars to Gehry or the Chinese guy Pei or whatever, to do this kind of building. I'm very ascetic here. When people say we must render big art accessible, this means not only Opera House but there should be a cafeteria, a bookstore there, and so on. Far from opening to the people, these cafeterias and book stores there are usually very exclusive for the rich people. I know many poor people who love opera and don't have time or money to go there. They just buy the cheapest tickets to see the opera or whatever.

This is why I try to boycott as much as possible all these social forms of today's art. I never go to art exhibitions, very rarely if I like some artist, very rarely - I try to ignore all this Biennale stuff or whatever. I try to keep out as much as possible out of this.

Ben: So you're resisting that symbolic position, that identity of "subversion" that they maybe want to bestow on you.

Slavoj: Yeah, because people are trying - even what happened basically yesterday, to make fun of this old communism, "another dangerous idea," whatever. No, I'm not too much of a pessimist here. People think I sold out making myself kind of intellectual 
star. No, it's not as simple as that. I can tell you that I am read in China among dissidents. I'm well read in South Africa, in Latin America and so on, which is why I notice now how I'm no longer - until now I was dismissed as a clown, "oh he's funny" and so on. Now that there is a new line on me started by that idiot, Adam Kirsch in the New Republic, "deadly court jester." They say no, you shouldn't be deceived by funny appearances, there is a dangerous message. A little totalitarian message behind it. They are getting the message slowly, this is not only jokes, that I am dangerous. So what? I don't care. I think the best way is do your job and ignore all this.

Ben: The 1,000-page Hegel book will help them take you seriously again.

Slavoj: I wonder how that will do, when they're saying he's just writing funny stuff. That will be more dangerous. Funny stuff, ha ha, but it's 1,000 pages again on Hegel. You know, it's really on Hegel. There was originally something on Wagner and Beckett, I threw even that out. It's strictly Hegel. It begins with long chapter on Plato, on Fichte, then it's Hegel, then it's Lacan, and at the end it's something about Heidegger and this will be interesting, quantum physics. It's a long chapter, a Hegelian way to provide a materialist reading of quantum physics, against this new age appropriation: "quantum physics is the end of materialist paradigm, we know now that spirit can create reality." All that bullshit, I totally oppose it.

But I like writing these books. Let's see what will happen. I just hope that, because of my relative fame through other books, at least it will not sell too bad, but it's totally different, again - a very, very difficult book. But my God, I'm not getting younger. I'm well aware that I can no longer behave as if I now have to get popular. No, some serious work - I will do it now or never.

I decided to do it now. After I finish this one, I will do for Penguin a short book they are now launching a series of short popular philosophical books and I accepted. They suggested to me the topic of "event." 4 And it's, I think, a crucial topic because you have three key philosophers today, Heidegger, Gilles Deleuze, Alain Badiou each of them has the notion of event as a central notion. And then I will try to develop how this fits with the big shift in modern philosophy from how appearances are no longer appearances. In a way, there is more truth in how things appear than in what things really substantially are.

So, I love this. I will go in detail. This will be a popular work, and then I don't think I will have the energy to do another thousand page book. But I know I will pay the price for it, in the sense of yes, I will do from time to time some political commentary and so on. But it's no longer where my heart is. I find this boring. Basically, I'm a very traditional philosopher. I believe in pure philosophy. I don't believe in all this bullshit. I think this is the new conformism, this idea: who needs abstract philosophy, deal with concrete problems, and so on.

No, I precisely believe in pure philosophy. I claim that if you try to instrumentalize philosophy, you precisely produce useless rubbish. This is why I try to provoke my Marxist friends, I told them that today we should - I used this joke a couple of times, maybe you know it. We should turn around [Marx's] eleventh thesis on Feueberach: "maybe in the 20th Century we tried to change the world too much, and now the time has come to interpret it more fundamentally." We don't know where we are.

I think that it looked in the 20th Century that we knew where we were. The problem is how to mobilize people to change. I really don't think we even have a good theory

${ }^{4}$ Slavoj Žižek, Event: Philosophy in Transit (London: Penguin, 2014). 
what is happening today with capitalism. Where are we moving now? What is happening in China? Is it still just a new face of capitalism? Is it a new type of authoritarian society? What is happening in biogenetics? What does this mean for - it shocks me. Are you aware, for example, that the next big breakthrough in sciences will be a kind of direct control or materialisation of our thinking process? I use this example often - I think it's quite shocking. In New York, they already succeeded in controlling the mind at the very elementary level, of a rat or mouse. I saw it myself. I contacted the guys.

The idea is that they can control at the very elementary level the basic neural commands for moving, left, right, and so on. So, you have a rat and you can control it like a remote control toy. Or even now I saw in England, they already had the wheelchair that you could control by thought itself. This is very elementary but nonetheless it works.

You don't even need the fingers of Steven Hawking. You just have to think intensely "forward," the computer can discern this elementary command and the wheelchair moves forward. There's something terrifying in this. All our sense of inner freedom is based on this distance, reality is out there, I have my inner life. What happens when this distance falls?

Again, these are tremendous theoretical problems. What will happen with our human identity? It's true that we are entering maybe into a new post-human era. Again, that's why I feel the time for philosophy is coming. It's a dangerous time.

Ben: Well, this ongoing "economic crisis" seems like it's a permanent crisis now.

Slavoj: Here I'm a much more modest pessimist. I don't think communism is around the corner, and so on. No, here I believe, although she's not a great theoretician but this Naomi Klein idea [in The Shock Doctrine], I think that capitalism has definitely used this crisis to become even more efficient and so on. Of course, every crisis is a chance, but for what? I'm much more of a pessimist here, so I don't see - of course it is pushing us, every crisis, to see if there are any openings. For example, one good result of this crisis is that everybody knows today that neo-liberalism not only is over but never even existed.

I'm getting so mad when people say we should fight neo-liberalism. My answer is "what neo-liberalism?" Where do you see neo-liberalism? Look at the most developed, not only China, even United States, is this a neo-liberal country? Are you crazy? How much is the state is spending to regulate economy? How much the state is intervening? Neo-liberalism was always a myth, I think.

It was an ideology used to put pressure on third-world countries, but isn't it that today, even before this crisis, but especially after 2008, state regulation is getting stronger and stronger? The state itself is getting stronger and stronger. This maybe opens up also some space in the sense that with state regulation maybe we can do not only - the only useful state regulation is not only to service the capital but it provides some space for different organization of healthcare or whatever education and so on.

We should fight here, but I certainly am not a cheap optimist in the old Marxist way, all capitalism is in a crisis. Crisis, we had one big crisis in Europe in 1920s and look what was the result? Nazism, Stalinism, and so on. Crises are always very, very dangerous. The sad thing is that people think today oh, but you see it's not only those who are too hopeful, a claim in Europe, you see it's not only anti-immigrant right, but we have now left demonstrations. Greece, Spain, and so on. Yeah, but you know, I'm following closely the situation. 
The tragedy is that if you look closely at it, there is no creative idea; like hundreds of thousands of people may be demonstrating in Greece, but this is pure protest against International Monetary Fund, but there are absolutely no alternate ideas like, what do they want, what is their plan to do against "Europe"? A Keynesian state, capitalism, self management or whatever. Even in all this new leftist critical movement I don't see any true ideas of how to really radically change the system.

Latino-American populism, I don't believe in it. I don't think Chavez is the answer. I think even there - I never was too keen on Chavez. Some people thought now a revolution is happening there. No, it's not. That model is also approaching its limit. That's our tragedy today. You see, people are revolting, but nobody is able to really propose an alternate model what do to.

Ben: I heard Jodi Dean and Doug Henwood talking about the Occupy Wall Street protests going on in New York. Henwood was saying they're obsessed with the process, and they can't get anywhere because no one wants to speak for anyone else.

Slavoj: Yeah, it's very nice "occupy Wall Street" and then what? Do they have an idea? I remember Doug Henwood gave a very nice pessimist talk years ago where he said, okay but what can we do? The only thing the left can think is solve the "rich," let's raise the taxes and so on.

You have even radical version of this. I mentioned it yesterday, this idea of "basic income," which means, let's allow capitalism but let's redistribute it in such a way that even those unemployed can live decent lives. This is just an interesting idea of how to save capitalism. The authors of this idea are very clear here. They say that maybe this is the true third way. We can have capitalism, but we can use its dynamic to provide for the unemployed and so on.

Now I find this very ironic because now what happened with the Marxist idea of exploitation? Now even the unemployed will exploit workers. It's obviously - ok, it's an interesting idea. I just don't think it's a solution. I don't think that at the worldwide level this idea of the basic citizen's income, or rather "rent," that this is the way out.

I'm much more of a pessimist here. Today's capitalism is more and more producing unemployment. It's no longer just the old unemployment [as in Marxist theory] where capitalism needs a reserve army and then to use it in a time when there is a need - so that when there is no longer a crisis. No, I think there is something structurally wrong with the system.

In the short term, why not citizens' income? But again, we really don't have an answer. 20th Century is over. Stalinist communism doesn't work. Let's face it, you in Australia or Scandinavian countries can still retain a lot of welfare state. Okay, it's good if you can. But at the worldwide level obviously, the welfare state is in a crisis.

Even you, now, your economy [in Australia], doesn't it depend quite a lot on exporting raw stuff to China? As I said yesterday this nice joke, once people - thirty years ago Deng Xiaoping thought only capitalism can save China. Now it looks like only China can save capitalism.

I think there still is this problem of large-scale organization for large-scale changes. We don't have the formula how to do it, but we will have to do it. Everybody admits that. Ecology, you can only cope with it at the large-scale level. How? Nobody has the formula.

I'm more a pessimist here. I don't like this, especially Trotskist left. You see, it's starting, even in European demonstrations. You know, communist revolution is around the corner. No, you know my old joke, you must have heard it; as an East European 
post-communist pessimist, When people tell me, "look, there already is light at the end of the tunnel." You know my answer? Yeah, "probably it's another train approaching us."

Let's be realists. As much as I am a communist in the sense that I see a need for an alternative, I think people should be made aware of how we are approaching a certain zero point. That's all I'm saying. I'm a modest conservative communist, if you put it like this. I more and more admire honest conservatives, you know why? Reactionaries are stupid. They think we'll return to old ways. Liberals, progressives are stupid. They believe in progress too naively. I like honest conservatives who are honest enough to admit deadlock and to admit that there is no easy way out. I think that my idea is the ideal pact is between honest conservatives and communists. Communists who accept from conservatives the complexity of the situation, no easy way out. But this is already Marx. Marx always emphasized how a good communist must learn a lot from honest intelligent conservatives.

Ben: Who do you include in that?

Slavoj: This will surprise you, Ayn Rand even. The worst of the worst, but you know what she said in her "Hymn to Money," that the only choice is that there is no freedom outside money. Money is alienation but money means I buy what I want, you sell what you want, there is a free space. You know where she is right in a way - her lesson is, do not all attempts to move beyond money to planned economy, demonstrate something of which Marx was already aware? If you abolish capitalism too directly, you don't create freedom but the old free capitalist relations of domination, of direct servitude, returns. It is a true problem of how to move beyond money and market exchange without regressing to pre-modern forms of domination. Isn't this the big lesson of Stalinism, Maoism, and so on? That de facto brutal forms of domination return. It's a serious problem. Why not, even from a crazy - she is a crazy person, Ayn Rand - she has a point unfortunately.

\section{References}

Cunningham, David. 2010. Capitalist Epics: Abstraction, Totality and the Theory of the Novel. Radical Philosophy 163: 11-23.

Žižek, Slavoj. 2014. Event: Philosophy in Transit. London: Penguin.

Žižek, Slavoj. 2012. Less Than Nothing: Hegel and the Shadow of Dialectical Materialism. London: Verso.

Žižek, Slavoj. 1992. Enjoy Your Symptom! Jacques Lacan in Hollywood and Out. New York: Routledge.

\section{About the Authors}

\section{Ben Gook}

Ben Gook is an ARC Research Fellow in the School of Social \& Political Sciences at the University of Melbourne. He was previously an Alexander von Humboldt Postdoctoral Fellow Humboldt University, Berlin, where he was also affiliated with the Humanities \& Social Change Centre. Publications include several articles, as well as two books, Divided Subjects, Invisible Borders: Re-Unified Germany after 1989 (Rowman \& Littlefield International, 2015) and the forthcoming Feeling Alienated: How Alienation Returned in Contemporary Capitalism (Cambridge UP, 2020). A new edited collection is underway for 2021 under the (provisional) title Libidinal Economies of Crisis Times: The Psychic Life of Capitalism. 
Slavoj Žižek

Slavoj Žižek is Eminent Scholar at Kyung Hee University, Seoul; Global Distinguished Professor of German at New York University; and the international director of the Birkbeck Institute for the Humanities at the University of London. He is the author of more than fifty books, including The Sublime Object of Ideology (Verso, 1989), Less than Nothing: Hegel and the Shadow of Dialectical Materialism (Verso, 2012), Incontinence of the Void: EconomicoPhilosophical Spandrels (MIT, 2017), and Sex and the Failed Absolute (Bloomsbury, 2020). 